\title{
MACHINE-LEARNING-BASED EVALUATION OF CORROSION UNDER INSULATION IN FERROMAGNETIC STRUCTURES
}

\author{
Ali SOPHIAN ${ }^{1 *}$, FARIS NAFIAH ${ }^{2,3}$, TEDDY SURYA GUNAWAN $^{4}$, \\ Nur AMalina MOHD YUSOF ${ }^{1}$ AND Ali Al-Kelabi ${ }^{1}$ \\ ${ }^{l}$ Smart Structures, Systems and Control Lab, Department of Mechatronics Engineering, \\ Kulliyyah of Engineering, International Islamic University Malaysia, \\ Jalan Gombak, 53100 Kuala Lumpur Malaysia \\ ${ }^{2}$ School of Engineering, London South Bank University, London, United Kingdom \\ ${ }^{3}$ NSIRC, TWI Ltd., Cambridge, United Kingdom \\ ${ }^{4}$ Department of Electrical and Computer Engineering, \\ Kulliyyah of Engineering, International Islamic University Malaysia, \\ Jalan Gombak, 53100 Kuala Lumpur Malaysia \\ *Corresponding author: ali_sophian@iium.edu.my
}

(Received: 10 $0^{\text {th }}$ November 2020; Accepted: $4^{\text {th }}$ April 2021; Published on-line: $4^{\text {th }}$ July 2021)

\begin{abstract}
Corrosion under insulation (CUI) is one of the challenging problems in pipelines used in the gas and oil industry as it is hidden and difficult to detect but can cause catastrophic accidents. Pulsed eddy current (PEC) techniques have been identified to be an effective non-destructive testing (NDT) method for both detecting and quantifying CUI. The PEC signal's decay properties are generally used in the detection and quantification of CUI. Unfortunately, the well-known inhomogeneity of the pipe material's properties and the presence of both cladding and insulation lead to signal variation that reduces the effectiveness of the measurement. Current PEC techniques typically use signal averaging in order to improve the signal-to-noise ratio (SNR), with the drawback of significantly-increasing inspection time. In this study, the use of Gaussian process regression (GPR) for predicting the thickness of mild carbon steel plates has been proposed and investigated with no signal averaging used. With mean absolute errors (MAE) of $0.21 \mathrm{~mm}$, results show that the use of GPR provides more accurate predictions compared to the use of the decay coefficient, whose averaged MAE is $0.36 \mathrm{~mm}$. This result suggests that the GPR-based method can potentially be used in PEC NDT applications that require fast scanning.
\end{abstract}

ABSTRAK: Hakisan di bawah penebat CUI adalah salah satu masalah yang mencabar dalam saluran paip yang digunakan dalam industri gas dan minyak kerana tersembunyi dan sukar dikesan tetapi boleh menyebabkan bencana. Teknik Pulsed eddy current (PEC) telah dikenal pasti sebagai kaedah ujian bukan pemusnah yang berkesan (NDT) untuk mengesan dan mengukur CUI. Sifat kerosakan isyarat PEC umumnya digunakan dalam pengesanan dan pengukuran CUI. Malangnya, sifat tidak tepat yang terkenal dari sifat bahan paip dan kehadiran pelapisan dan penebat menyebabkan variasi isyarat yang mengurangkan keberkesanan pengukuran. Teknik PEC semasa biasanya menggunakan rata-rata isyarat untuk meningkatkan nisbah isyarat-ke-kebisingan (SNR), dengan kelemahan peningkatan masa pemeriksaan dengan ketara. Dalam kajian ini, penggunaan regresi proses Gauss (GPR) untuk meramalkan ketebalan plat keluli karbon ringan telah diusulkan dan diselidiki dan tidak ada rata-rata isyarat yang digunakan. Dengan ralat mutlak (MAE) 0,21 mm, hasil menunjukkan bahawa penggunaan GPR memberikan ramalan yang lebih tepat dibandingkan dengan penggunaan pekali peluruhan, yang rata- 
rata MAE adalah 0,36 mm. Hasil ini menunjukkan bahawa kaedah berasaskan GPR berpotensi digunakan dalam aplikasi PEC NDT yang memerlukan pengimbasan pantas.

KEYWORDS: corrosion under insulation; pulsed eddy current; non-destructive testing; machine learning; fast scanning

\section{INTRODUCTION}

Industrial oil and gas infrastructures, including the transmission pipelines that are used in transportation and distribution, require regular inspection as stipulated by governmental safety regulations all around the world to prevent catastrophic accidents. Many of these structures are made of carbon steel materials and covered by insulation for their protection or maintaining the high temperature of the oil or gas flowing inside them. A thin cladding is usually placed outside the insulation to hold the insulation in place and to stop water from seeping into the insulation that may cause or accelerate the growth of corrosion on the outer surface of the pipe. Such structures, whose illustration can be seen in Fig. 1, will benefit from non-destructive inspection techniques that are able to penetrate through the insulation and cladding, and therefore, detect any presence of the corrosion under insulation (CUI). CUI is considered a crucial problem with these pipes [1,2]. The ability to detect and assess CUI in the pipes without the removal of the insulation is very beneficial [3]. Removal of the insulation takes time, which, in turn, would lengthen the downtime of the plant and would require new costly replacements of the insulation or coating.

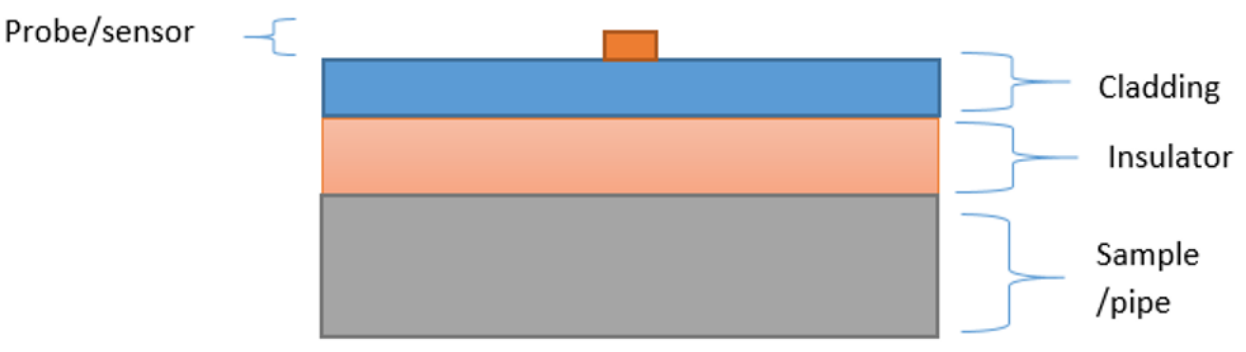

Fig. 1: Typical setting of insulated pipes with a probe sitting on its cladding.

Pulsed eddy current (PEC) non-destructive testing (NDT) has been identified as one of the solutions with the most potential for non-contact evaluation of corrosion in carbon steel structures [4], which are either coated or otherwise. The low frequency components of the excitation field allow deep penetration into the ferromagnetic structure. For such structures, magnetic saturation has been proposed, although many have proposed the use of PEC without magnetically saturating the sample.

There have been several different PEC signal features proposed by researchers [3]. The signal features also depend on the type of the sensing device, whether it is an inductive coil or a magnetic field sensor. Mostly, the features are related to the decay properties of the signals, especially the gradient of the later stage of the decay, thanks to its high correlation to the thickness of the tested structure and its insensitivity to the variation in the distance between the probe and the sample, which is known as the standoff or lift-off. There have been promising results reported, although most of these have been applied on signals obtained by using inductive coils. A technique based on the signal's inverse time derivative $|\nabla|^{-1}$ is shown to allow in-situ calibration and improved estimation compared to the $\tau_{0}$ feature, which is the time at which the induced current's 
diffusion phase ceases [1]. An accuracy of $0.67 \mathrm{~mm}$ has been achieved with averaging of 16 signals. Time to peak as a feature was proposed and its performance was shown to be good on simulation data, while no experimental data were reported [4]. Other time domain features have also been discussed in other reports, such as [5-7]. The use of a magnetic sensor, instead of an inductive coil, offers benefit in terms of the spatial resolution. However, relatively less studies have been reported where a magnetic sensor was used. Cheng et al. used anisotropic magnet resistance (AMR) sensors and the feature used was the decay coefficient, which is the reciprocal of the decay rate of the magnetic field density in the logarithmic scale [8].

PEC signals are known to be noisy. Some noise reduction techniques have been presented $[9,10]$, and the testing gets even more challenging due to inhomogeneity in ferromagnetic materials [11]. The use of signal averaging is effective to some extent, however it increases the measurement time significantly, depending on the number of signals used. This will prevent fast scanning applications using the PEC. In this paper, machine learning is used to predict the thickness of the insulated ferromagnetic sample without applying signal averaging. Machine learning, including its latest development known as deep learning, has embraced countless applications in various sectors of industry. Non-destructive testing (NDT) is not an exception to this current trend, and eddy NDT current techniques have also seen the applications of machine learning, such as the works reported in $[12,13]$. In this study, the use of machine learning in processing PEC signals obtained without signal averaging is presented.

\section{MODELLING OF PEC AND CUI}

An axisymmetric 2D model, as shown in Fig. 2, was built using COMSOL Multiphysics which consists of a few layers, namely the carbon steel sample, the insulation, and the cladding. The inner and outer radii of the excitation coil were $100 \mathrm{~mm}$ and $110 \mathrm{~mm}$ respectively, while the height of coil was $6 \mathrm{~mm}$. In this work, the model is used to verify the trends in the magnetic field density that will be sensed by the sensor when the lift-off and sample thickness are varied. It is not intended to find the actual magnitudes of the field.

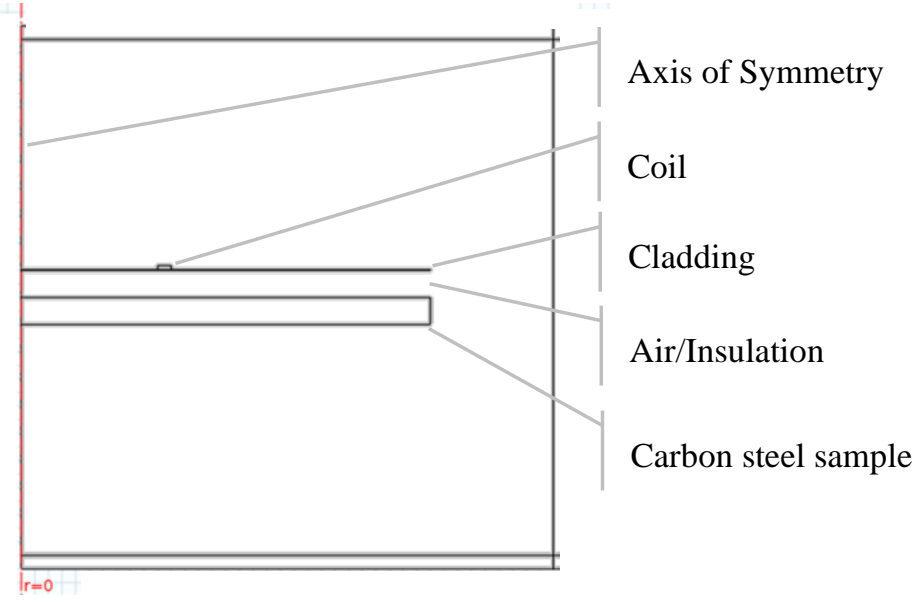

Fig. 2: 2D-axisymmetric finite element model of the PEC system on an insulated sample with a cladding. The model was developed on COMSOL software.

The conductivity and relative permeability of the sample were set to $5 \times 10^{6} \mathrm{~S} / \mathrm{m}$ and 100 , respectively. The thickness was varied from $9 \mathrm{~mm}$ to $12 \mathrm{~mm}$ with an increment of 1 
$\mathrm{mm}$. For the cladding, its thickness was $0.5 \mathrm{~mm}$ and two different sets of permeability and conductivity values were used to simulate stainless steel and aluminium materials.

The model was run for both different sample thicknesses and different insulation thicknesses. The results were plotted in the graphs shown in Fig. 3 and they verify that the slope of the signals is affected by the sample thickness but not by the lift-off, as has been reported by other researchers.

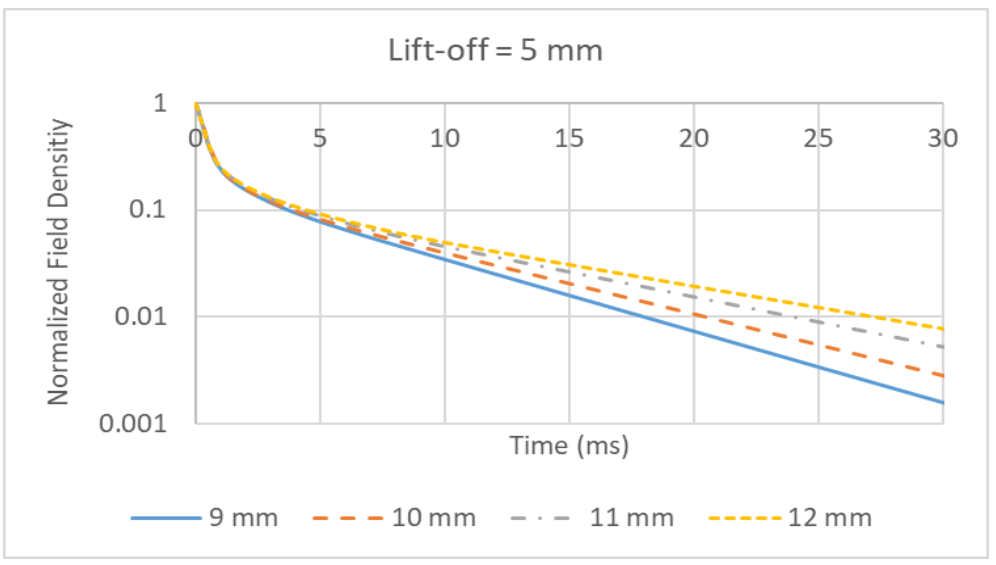

(a)

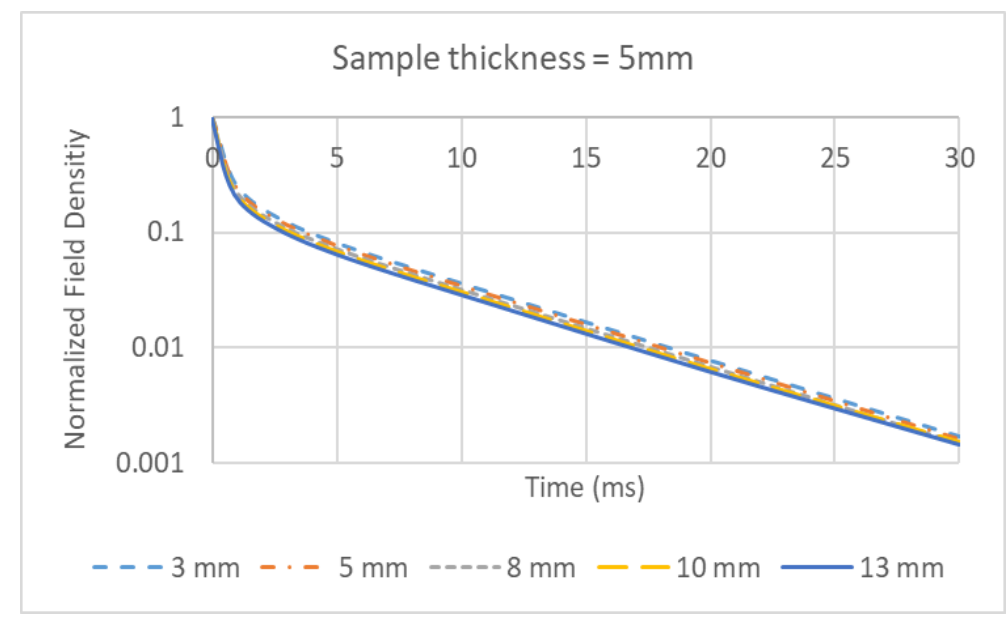

(b)

Fig. 3: Typical signals obtained by using the developed PEC models, (a) for different thicknesses and (b) for different lift-offs.

\section{METHODOLOGY}

In this study, the thickness approximation techniques using the gradient coefficient and machine-learning-based regression techniques will be compared on PEC signals that have been obtained without any signal averaging.

\subsection{Experimental Setup}

A PEC system was built, consisting of a probe, a data acquisition, and a laptop running LabView. The probe consisted of an excitation coil and a Hall-effect device. A ferrite core was used for concentrating the magnetic flux and strengthening the Hall device's output signal. Through the LabView code, the signal sampling was set at 100 $\mathrm{kS} / \mathrm{s}$ and the pulse width was $25 \mathrm{~ms}$. The LabView code saved the acquired data to be 
analysed. The inner and outer diameters of the coil were $100 \mathrm{~mm}$ and $110 \mathrm{~mm}$, respectively. Its height was $6 \mathrm{~mm}$ and it had 200 turns. A MOSFET was used to switch the high excitation currents on and off with a pulse width of $25 \mathrm{~ms}$ driven to the excitation coil. Fig. 4 shows the block diagram of the PEC setup used in this work.

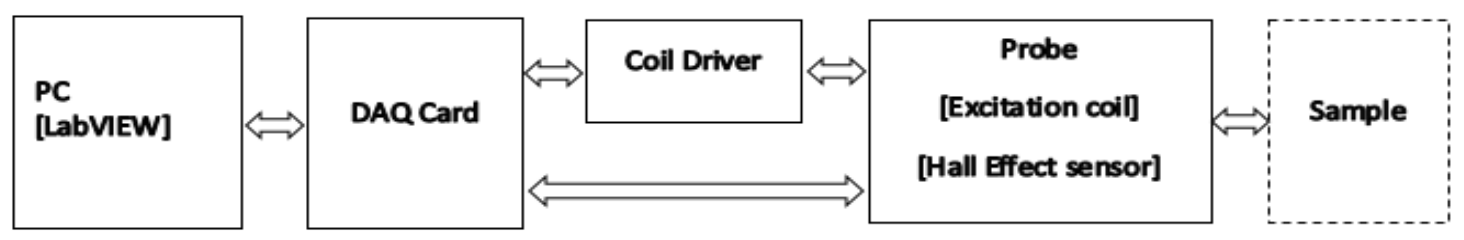

Fig. 4: The block diagram of our PEC system.

Corrosion or wall loss was simulated by thicknesses that were less than the thickness of the sound structure. Square plate samples with surface dimensions of $300 \mathrm{~mm} \times 300$ $\mathrm{mm}$ were used and they had different thicknesses, which were 9.12, 10.02, 11.06, and $12.08 \mathrm{~mm}$. The stand-off was also varied at 3, 5, 8, 10, and $13 \mathrm{~mm}$. Fifty signals were obtained for each combination of thickness and stand-off. Two different materials were used for the cladding, which were aluminium and stainless steel. The thickness of the cladding was $0.5 \mathrm{~mm}$.

\subsection{Signal Processing (Data Pre-processing)}

The falling edge of the Hall effect signal and its decay properties were used to predict the thickness. In order to improve the signal-to-noise ratio (SNR), a median filter was applied to reduce the high-frequency noise. The logarithmic values of the signal were used to find the decay coefficient. Normalization to unity was employed to reduce the effects of the variation in the magnitude of the magnetic field that was induced by the excitation coil, which may be caused by the sample's inhomogeneity and the change in the excitation coil's temperature, among others. Fig. 5 shows typical signals that have been averaged in order to increase the clarity of the shape of the signals. For the purpose of determination of the decay coefficient, part of the signal that has been used is $10 \mathrm{~ms} \leq t \leq 35 \mathrm{~ms}$.

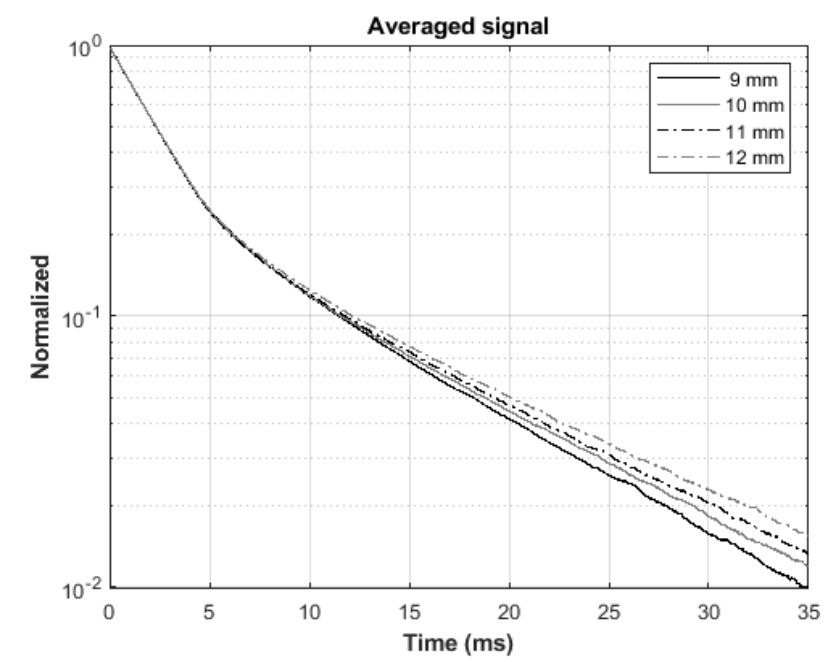

Fig. 5: Typical averaged signals for different sample thicknesses. 


\subsection{Machine-Learning-based Regression}

Based on preliminary observation, the Gaussian process regression (GPR) model consistently provided the best result among other regressions. GPR is a non-parametric and non-linear kernel-based model, and it uses a Bayesian approach to model the uncertainty of the prediction. It has been widely used in various applications, thanks to its simplicity and its good performance when small datasets are available, among others. The kernel function that models the similarity between similar predictors was chosen to be the exponential kernel, which is defined by [14],

$$
k\left(x_{i}, x_{j} \mid \theta\right)=\sigma_{f}^{2} \exp \left(-\frac{r}{\sigma_{l}}\right) \text {, }
$$

where $\sigma_{l}$ is the characteristic length scale and $r$ is the Euclidean distance between predictors $x_{i}$ and $x_{j}$, and $\theta$ is the vector containing the parameters for the kernel.

The decay of the magnetic field that is sensed by the Hall device is set as the predictor variables for the regression model.

\subsection{Model Validation and Testing}

Validation was performed on machine leaning models in order to test their performance after training, including the generalization of the model. Due to the limited quantity of data and to avoid overfitting the model, a cross validation technique known as $\mathrm{k}$-fold was employed in this work. In this technique, the data were split into $k$ groups and the model was trained and validated $k$ times. In every iteration, one different group was excluded from the training and used only in the validation, therefore each and every group of data was used for validation. In this work, 5-fold was used meaning that the data was split into commonly used 5 groups. Seventy percent of the overall data that were chosen randomly were used for this training and validation exercise. The remaining $30 \%$ of the dataset were used to test and compare the model against the performance of the approach that uses the $1 /$ gradient feature.

The performances of both methods, namely decay coefficient and GPR, were evaluated and compared using the following metrics: root mean squared error (RMSE), Rsquared, mean squared error (MSE), and mean absolute error (MAE). All these metrics are already well known and widely used for evaluating performances of both measurement systems and machine learning models.

\section{RESULTS AND DISCUSSION}

Fig. 6 exhibits the plots of the predicted thickness generated using both methods with the experimental data obtained from all different lift-offs, sample thicknesses, and cladding materials. The error bars in the plots represent the standard deviation. The performance metrics are shown in Table 1.

Table 1: Performance metrics of both methods

\begin{tabular}{cccccc}
\hline Method & Cladding & $\begin{array}{c}\text { RMSE } \\
(\mathbf{m m})\end{array}$ & R-squared & $\begin{array}{c}\text { MSE } \\
(\mathbf{m m})\end{array}$ & $\begin{array}{c}\text { MAE } \\
(\mathbf{m m})\end{array}$ \\
\hline Decay & Stainless steel & 0.4611 & 0.825 & 0.213 & 0.373 \\
coefficient & Aluminium & 0.420 & 0.856 & 0.177 & 0.346 \\
GPR & Stainless steel & 0.298 & 0.928 & 0.089 & 0.215 \\
Exponential & Aluminium & 0.266 & 0.942 & 0.071 & 0.198 \\
\hline
\end{tabular}




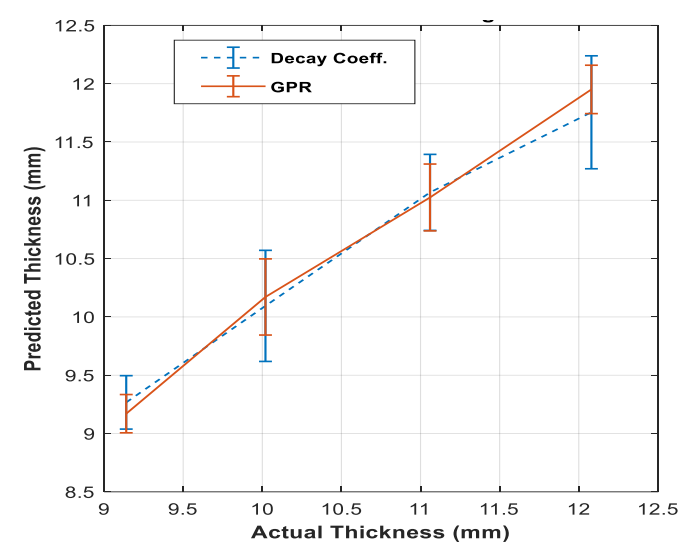

(a)

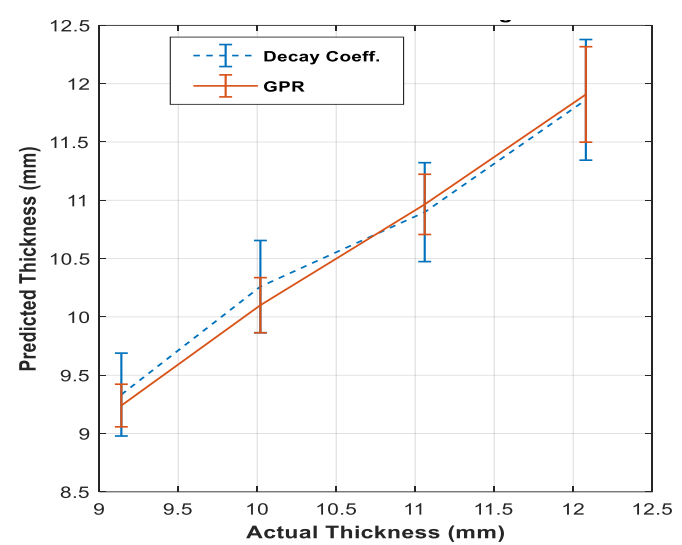

(b)

Fig. 6: The averaged predicted thickness with error-bars representing the standard deviation of the measurement error, (a) aluminum cladding, (b) stainless steel cladding.

Both the plots and the table demonstrate that the GPR exponential model outperformed the approach using the decay coefficient in terms of both the nominal error and the spread of errors. The averaged RMSE, R-squared, MSE and MAE of the GPR model are better by $36.0 \%, 11.2 \%, 59.0 \%$ and $42.6 \%$ respectively than those of predicted thicknesses using the decay coefficient.

\section{CONCLUSION}

In recent years, machine learning - a subset of artificial intelligence - has developed very rapidly and seen applications in various sectors, with deep learning being the latest development. Insulated industrial pipes develop corrosion or wall thinning that is hidden and challenging to be detected. This work proposed the use of machine learning for processing PEC signals, especially when the SNR was relatively high (as no signal averaging was used in order to improve the scanning speed), and therefore reducing the inspection time. The experimental data analysis shows that the GPR exponential model generated better results with both lower nominal errors and lower error variances, represented in the improvements in the RMSE, R-squared, MSE and MAE, by 36.0\%, $11.2 \%, 59.0 \%$, and $42.6 \%$, respectively. This suggests that the machine learning method can potentially be used in the applications where fast scanning is required.

\section{REFERENCES}

[1] Nafiah F, Tokhi MO, Majidnia S, Rudlin J, Zhao Z, Duan F. (2020) Pulsed Eddy current: Feature extraction enabling in-situ calibration and improved estimation for ferromagnetic application. J. Nondestruct. Eval., 39(52). doi: https://doi.org/10.1007/s10921-020-00699w.

[2] Nicola S, Carreto V, Mentzer RA, Mannan MS. (2013) Corrosion under insulation detection technique. In Proceedings of Corrosion 2013: 17-21 March 2013; Orlando, Florida

[3] Sophian A, Tian G, Fan M. (2017) Pulsed Eddy Current Non-destructive Testing and Evaluation: A Review. Chinese J. Mech. Eng. (English Ed.), 30:500-514

[4] Xu Z, Wu X, Li J, Kang Y. (2012) Assessment of wall thinning in insulated ferromagnetic pipes using the time-to-peak of differential pulsed eddy-current testing signals. NDT E Int., 51:24-29. doi: https://dx.doi.org/10.1016/j.ndteint.2012.07.004.

[5] Ulapane N, Nguyen L. (2019) Review of pulsed-Eddy-current signal feature-extraction methods for conductive ferromagnetic material-thickness quantification. Electron., 8(5):470. doi: https://doi.org/10.3390/electronics8050470. 
[6] Ulapane N, Alempijevic A, Calleja TV, Miro JV. (2017) Pulsed Eddy current sensing for critical pipe condition assessment. Sensors, 17(10):2208. doi: https://doi.org/10.3390/s17102208.

[7] Buck JA, Kramer C, Lei J, Lepine BA. (2016) Field implementation of a transient Eddy current system for carbon steel pipe thickness measurements. In Proceedings of 6th International CANDU In-Service Inspection Workshop: 15-17 November 2016; Ontario

[8] Cheng W. (2012) Pulsed Eddy current testing of carbon steel pipes' wall-thinning through insulation and cladding. J. Nondestruct. Eval., 31(3): 215-224. doi: https://doi.org/10.1007/s10921-012-0137-9.

[9] Huang C, Xinjun W, Zhiyuan X, Kang Y. (2010) Pulsed Eddy current signal processing method for signal denoising in ferromagnetic plate testing. NDT E Int., 43(7): 648-653. doi: https://doi.org/10.1016/j.ndteint.2010.06.010.

[10] Huang C, Wu X. (2015) An improved ferromagnetic material pulsed eddy current testing signal processing method based on numerical cumulative integration. NDT E Int., 69: 35-39.

[11] Sophian A, Tian GY, Taylor D, Rudlin J. (2003) Flaw detection and quantification for ferromagnetic steels using pulsed eddy current techniques and magnetization. Laser Metrology and Machine Performance VI, pp 381-390.

[12] Daura LU, Tian GY, Yi Q, Sophian A. (2020) Wireless power transfer-based eddy current non-destructive testing using a flexible printed coil array: WPT based FPC-ECT. Philos. Trans. R. Soc. A Math. Phys. Eng. Sci., 378:20190579 doi: https://doi.org/10.1098/rsta.2019.0579.

[13] Nafiah F, Sophian A, Khan MR, Zainal Abidin IM. (2018) Quantitative evaluation of crack depths and angles for pulsed eddy current non-destructive testing, NDT E Int., 102:180-188. doi: 10.1016/j.ndteint.2018.11.019.

[14] Kernel (Covariance) Function Options [https://www.mathworks.com/help/stats/kernelcovariance-function-options.html] 